\title{
РЕПАТРІАЦЇ̈ - НІ! ПОЛІТИЧНИЙ ПРОТЕСТ ДІПІ ЗАХІДНОЇ НІМЕЧЧИНИ У ДРУГІЙ ПОЛОВИНИ 1940-Х РР.
}

Анотація: На основі широкої джерельної бази ставимо за мету визначити $i$ проаналізувати форми та результативність політичного протесту переміщених осіб і біженців 3 України у Західній Німеччині у другій половині 1940-х рр. як реакцію на примусову репатріацію до СРСР. Під час проведення дослідження використано такі загальнонаукові методи, як аналіз $i$ синтез, індукцію й дедукцію. Серед спеціально-історичних методів слід назвати методи бібліографічної й архівної евристики, порівняльно-історичний, проблемно-хронологічний $i$ біографічний. У цьому дослідженні послуговуємося терміном «політичний протест», який розуміємо наступним чином: політичний протест - індивідуальна чи групова дія переміщених осіб і біженців з України, яка полягала у вияві незгоди з кампанією примусової репатріації до СРСР, що розгорнулася у другій половині 1940-хрр. у Західній Німеччині. Вперше виокремлено та проаналізовано форми і наслідки політичного протесту переміщених осіб і біженців з Украӥни у Західній Німеччині у другій половині 1940-х рр.

Ключові слова: репатріація, переміщені особи та біжениі з Украӥни, політичний протест, Західна Німеччина, СРСР

У лютому 1945 р. на конференції в Ялті Й. Сталін поставив питання жорстко: усі радянські громадяни мають бути повернені до СРСР. Така позиція очільника Радянського Союзу зумовлювалася передовсім бажанням запобігти формуванню за кордоном опозиції радянській владі та поверненням трудових ресурсів для відбудови зруйнованого народного господарства. Як наслідок, 11 лютого 1945 р. між Й. Сталіним, В. Черчиллем і Ф. Рузвельтом було підписано таємну угоду про повернення військовополонених англійців та американців в їхні країни, а також про повернення, незалежно від їх бажання, усіх військовополонених і переміщених осіб до СРСР. Репатріації до СРСР підлягали лише ті радянські громадяни, які проживали на території Радянського Союзу в кордонах, дійсних станом на 1 вересня 1939 р.

На практиці представники радянських репатріаційних комісій намагалися відправляти до СРСР усіх, навіть емігрантів, які виїхали за кордон після жовтня 1917 р. у квітні 1945 р. на нараді в НКВС нарком внутрішніх справ СРСР Лаврентій Берія пояснив, що «між полоненими, яких вивезли або виїхали добровільно, немає різниці» і що «кожен 3 них, залишившись в руках ворогів СРСР, може принести білыше шкоди, ніж тисячі шкідників всередині країни». Керівництво Радянського Союзу розуміло, що повоєнна

\footnotetext{
" Подобєд Олена Андріївна - доктор історичних наук, доцент, доцент кафедри джерелознавства та спеціальних історичних дисциплін, Національний педагогічний університет імені М.П. Драгоманова (Київ, Україна); ORCID: https://orcid.org/0000-0002-7819-1439; e-mail: o.a.podobyed@npu.edu.ua

${ }^{1}$ Русский Берлин: 1920-1945: Международная научная конференция / Науч. ред. Л.С. Флейшмана. Москва: Русский путь, 2006. С. 426.
} 
еміграція є політичною, а іï представники вважають своєю місією донести правду про злочинну діяльність радянської влади до всього світу.

у 1929 р. на дипломатичній конференції у Женеві було ухвалено Конвенцію про поводження з військовополоненими, яка набрала чинності за два роки. Радянський Союз не ратифікував цей документ. Сталін виходив з того, що всіх військовополонених, незалежно від того, за яких обставин вони опинилися у полоні, слід вважати зрадниками. Тому й не дивно, що американські військовополонені з радістю поверталися на батьківщину, де їх зустрічали як героїв, а радянські - опиралися поверненню на «родіну», яка таврувала їх зрадниками. Масова репатріація до СРСР супроводжувалася численними протестними акціями, до яких були не готові ні союзники, ні ЮНРРА².

Попри це, відповідно до Ялтинських домовленостей, а також зважаючи на те, що на захоплених радянськими військами територіях знаходилися табори, в яких перебували англійські й американські військовополонені, союзники сприяли примусовій репатріації до СРСР. Однак про це не воліли говорити вголос. В англійській, американській чи радянській пресі тих часів йшлося про повернення радянських громадян до СРСР й жодного слова про насильницький характер репатріації. ДіПі не йняли віри «наївності» альянтів у їхніх судженнях про радянських союзників. «Невже вони справді думали, що вдома нас чекають 3 хлібом-сіллю. А якщо ні, як же вони могли сприяти примусовому поверненню нас на Батьківщину?!»3, - запитувала через 70 років після цих трагічних подій колишня ДіПі Галина Воскобійник.

Поки західна преса закривала очі на дії СРСР, про справжню суть репатріації волали українські газети, засновані у другій половині 1940-х рр. у Західній Німеччині, однак їхні голоси світовій громадськості було нелегко почути. Перші публікації у західній пресі про ганебну участь Великої Британії та США у примусовій репатріації радянських громадян до СРСР з'явилися лише у 1970-1980-х рр.

Аналіз останніх досліджень $і$ публікацій. Окремі аспекти проблеми репатріації переміщених осіб і біженців з України до СРСР перебували в полі зору радянських ${ }^{4}$, закордонних ${ }^{5}$, зарубіжних українських ${ }^{6}$ і сучасних українських ${ }^{7}$ істориків. Проте, на сьогодні відсутнє дослідження комплексу протестних дій ДіПі Західної Німеччини, спрямованих проти примусової репатріації до СРСР.

Mema cmammi. На основі широкої джерельної бази авторка ставить за мету визначити і проаналізувати форми та результативність політичного протесту переміщених

\footnotetext{
${ }^{2}$ УНРРА, або ЮНРРА (англ. United Nations Relief and Rehabilitation Administration (UNRRA) - «Адміністрація Організації Об'єднаних Націй для допомоги і відбудови») - міжнародна організація для допомоги потерпілим у Другій світовій війні країнам. - Прим. ред.

${ }_{3}^{3}$ Воскобійник Г. Свобода і далі: шлях української жінки до нового життя в Америці. Львів: ЛА «Піраміда», 2018. C. 105.

${ }^{4}$ Брюханов А.И. Вот как это было: 0 работе миссии по репатриации советских граждан. Москва: Госполитиздат, 1958. 208 с.; Земсков В.Н. К Вопросу о репатриации советских граждан 1944-1951 гг. История CCCP. 1990. № 4 . C. $26-41$.

${ }^{5}$ Bethell N. The last secret Forcible Repatriation to Russa 1944-1947. London, 1974. 224 p.; Eliot M.R. The Repatriation Issue in Soviet-American Relations 1944-1947. University of Kentucky, 1974. 412 p.

${ }^{6}$ Dyczok M. The Grand Alliance and Ukrainian Refugees. Oxford: St. Antony's College, 2000. 277 p.

${ }^{7}$ Куницький М. Примусова репатріація радянських громадян до СРСР після Другої світової війни (український вектор). Луцьк: ВАТ «Волинська обласна друкарня», 2007. 248 с.
} 
осіб і біженців з України у Західній Німеччині у другій половині 1940-х рр. як реакцію на примусову репатріацію до СРСР.

Джерела. Основу джерельної бази дослідження становлять матеріали архівів, результати опитування переміщених осіб і біженців з України, низка документів, вміщених у книзі «Регенсбур: статті - спогади - документи», спогади сучасників подій, матеріали преси, а також художні твори. Архівні матеріали представлені документами органів влади $\mathrm{CPCP}^{9}$. У 2020 р. авторкою було проведено опитування переміщених осіб і біженців 3 України, а нині громадян США. Під час написання цього дослідження використано заповнені анкети чотирьох респондентів - Валентина Забіяки (1933 р.н.), Олеся Ломацького (1932 р.н.), Л.3.О. (1935 р.н.) та Л.О. (1935 р.н. ${ }^{10}$, які у другій половині 1940-х рр. перебували на території Західної Німеччини.

Інформативними є спогади та щоденники сучасників подій - Олекси Воропая, Галини Воскобійник, Лариси Залеської Онишкевич, Михайла Клименка, Григорія Костюка, Катерини Кричевської-Росандіч, Анатолія Мірошника, Миколи Рутченка-Рутича, Івана Юрченка ${ }^{11}$. Згадані джерела особового походження дають можливість побачити події примусової репатріації очима а́кторів, відчути психологічний клімат епохи ДіПі. У свою чергу використання творів художньої літератури Ірени Коваль і Марини Гримич ${ }^{12}$ дає можливість побачити проблему репатріації у рецепціях сучасних письменниць.

Виклад основного матеріалу. По завершенні Другої світової війни, за влучним висловом колишньої ДіПі Лариси Залеської Онишкевич, почалася інша війна, «війна

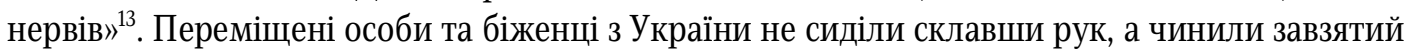
опір примусовій репатріації до СРСР. Їхній протест можна кваліфікувати як політичний. Американські дослідники Дж. Дженкінс і Б. Кландерманс визначають політичний протест як «колективну дію чи систему колективних дій, що спрямовані на зміну систем представницької та/або виконавчої влади, державної політики, що проводиться або взаємовідносин між громадянами і державою в цілому» ${ }^{14}$. Надалі під політичним протестом

\footnotetext{
${ }^{8}$ Регенсбург: статті - спогади - документи. До історії української еміграції в Німеччині після Другої світової війни / Гол. редкол. Ом. Кушнір. Нью-Йорк; Париж; Сидней; Торонто: Друкарня Мирона Баб’юка, 1985. 684 с. ${ }^{9}$ Центральний державний архів громадських об’єднань України (ЦДАГО України). Ф. 1. Оп. 23. Спр. 5166.

${ }^{10}$ Особистий архів О.А. Подобєд. Анкета Валентина Забіяки (1933 р.н.); Особистий архів О.А. Подобєд. Анкета Олеся Ломацького (1932 р.н.); Особистий архів О.А. Подобєд. Анкета Л.3.О. (1935 р.н.); Особистий архів О.А. Подобєд. Анкета Л.О. (1933 р.н.).

${ }^{11}$ Воропай О. В дорозі на Захід. Щоденник утікача. Лондон: Українська видавнича спілка, 1970. 281 с.; Воскобійник Г. Свобода і далі: шлях української жінки до нового життя в Америці. Львів: ЛА «Піраміда», 2018. 284 с.; Залеська ОнишкевичЛ. Бомби, границі і два праві черевички. Друга світова війна очима дитинибіженця. Львів: Літопис, 2018. 258 с.; Клименко М. Из трех миров: Пережитое... непреходящее: «Долг, завещанный от Бога». Москва: Русский путь, 2011. 396 с.; Костюк Г. Зустрічі і прощання. Спогади: у 2 кн. / передм. М. Жулинський. Київ: Смолоскип, 2008. Кн. 2. 2008. 512 с.; Кричевська-Росандіч К. Мої спогади. Київ: Родовід, 2006. 208 с.; Мірошник А. Музика і доля. Київ: Музична Україна, 2008. 172 с.; Рутченко-Рутыч Н.Н. Средь земных тревог. Воспоминания. Москва: Русский путь, 2012. 607 с.; Бо Ти любив, в душі беріг, як скарб коштовний, Україну: життєпис українського патріота Івана Демидовича Юрченка / Упоряд. О. Мельничук. Вінниця: Нілан-ЛТД, 2015. 266 с.

${ }^{12}$ Коваль I. Незаземлені. Роман. Львів: Видавництво Анети Антоненко, 2016. 204 с.; Гримич М. Клавка. Роман. Київ: Нора-Друк, 2019. 336 с.

${ }^{13}$ Залеська Онишкевич Л. Бомби, границі і два праві черевички... С. 224.

${ }^{14}$ Сабитов М.Р. Политический протест: теоретические проблемы дефиниции и типология. Современные исследования социальных проблем. 2012. № 9. URL: www.sisp.nkras.ru
} 
у цьому дослідженні розуміється індивідуальна чи групова дія переміщених осіб і біженців 3 України, яка полягає у вияві незгоди з кампанією примусової репатріації до СРСР, що розгорнулася у другій половині 1940-х рр. у Західній Німеччині.

Усі протестні дії, до яких протягом другої половини 1940-х рр. вдавалися переміщені особи та біженці з України, можна визначити як активні та пасивні. Активні поведінкові практики, до яких вдавалися ДіПі, становили більшість, вони здійснювалися переважно публічно й могли бути організованими та стихійними. Послідовно проаналізуємо їх.

Найбілыш інтенсивна примусова репатріація до СРСР відбувалася у 1945 р., доки уряди Великої Британії та США прийняли рішення про припинення примусової репатріації до Радянського Союзу. За цей час до України було вивезено понад 2 млн. осіб. Військові влаштовували на ДіПі справжні «облави», погрожували їм вогнепальною зброєю, переконували за допомогою прикладів і кийків, силоміць заштовхували у вантажівки і товарні вагони та відправляли до Східної Німеччини, яка перебувала під контролем СРСР. Саме на цей період припав і найбілыш активний опір переміщених осіб і біженців 3 України, які боронячи себе перед військами альянтів, подекуди змушені були застосовувати проти них фізичну силу.

У 1983 р. в американській газеті «The Wall Street Journal» була опублікована стаття професора Техаського університету Р. Девісона, який у серпні 1945 р., як військовий армії США, брав участь у вилові радянських громадян для їхньої подальшої репатріації до СРСР. Військове командування поставило за мету за будь-яку ціну (навіть, якщо доведеться вбити) загнати ДіПі у вантажівки. Професор наголосив, що коли командир повідомив, що Й. Сталін обіцяв не завдавати ДіПістам шкоди, у військових це викликало тихий сміх. Сам 19-річний Р. Девісон думав, що Сталін, мабуть, вб'є цих людей.

Під час одного з таких рейдів у серпні 1945 р. у Кемптені останнім форпостом переміщених осіб і біженців стала церква. Однак військових це не зупинило, вони увійшли до храму, розпочалася бійка, у результаті якої побитих прикладами ДіПі військові вигнали 3 храму Божого та повантажили в машини. В однієї жінки стався серцевий напад, а інша підійшла до Р.Девісона й ламаною англійською сказала: «Я думала, що американці хороші $»^{15}$. Ці слова професор запам'ятав на все життя. Письменниця Ірена Коваль у своєму автобіографічному романі «Незаземлені» навела типове звернення ДіПі до американських солдатів: «Невже ми для вас, американських солдатів, небажані люди, торба клопоту, що вам кортить бачити, як ми поляжемо в землю? Ви хочете, щоб ми їхали додому - тобто до Сибіру?! Додому, щоб нас убили пострілом у голову?»" ${ }^{16}$ Подібні ситуації відбувалися і на периферії «галактики ДіПі» - в Італії. Російський історик Петро Базанов наводить приклади збройного опору переміщених осіб і біженців з Росії, що відбулися 8 травня 1947 р. у таборі Річчоні поблизу Ріміні ${ }^{17}$.

Заради об'єктивності слід згадати і прояви людяності з боку «людоловів». Приміром, мешканка ДіПі-табору в Кемптені Ірина Лук'янова згадувала, як один американський солдат напередодні «облави» попередив таборян. Вони сховалися в лісі, у результаті чого

\footnotetext{
${ }^{15}$ Davison R.R. «I Thought Americans Were Good». The Wall Street Journal. 1983. 23 September. P. 3.

${ }^{16}$ Коваль $I$. Незаземлені... С. 36.

${ }^{17}$ Русские в Италии: Культурное наследие эмиграции: Международная научная конференция / Сост. М.Г. Талалая. Москва: Русский путь, 2006. С. 182.
} 
вдалося репатріювати з 410 осіб лише $80^{18}$. Проте такі випадки були поодинокі.

«Краще вмерти, ніж вертатися на тортури і Сибір», - так схарактеризував свою перспективу повернення до СРСР актор Михайло Лялька. У часи примусової репатріації до СРСР, особливо у 1945 р., серед переміщених осіб і біженців з України набули поширення суӥцидальні настрої. Загнані у «глухий кут», беззахисні люди перебуваючи у стані панічного страху, вкорочували собі віку аби лишень не потрапити до радянських «людоловів». Суӥцидальні настрої опановували представників різних верств суспільства, не стало винятком навіть духовенство. До самогубства, як форми політичного протесту, вдавалися не лише переміщені особи та біженці з України, а й з інших країн, включно з Росією.

Подекуди траплялися воістину трагічні випадки, коли голова сімї̈ змушений був позбавити життя дружину та дітей, а потім і сам йшов у засвіти. Сучасниця подій Галина Воскобійник у своїй книзі спогадів навела текст передсмертної записки, яку залишив їх сусід перед тим, як застрелити дружину, п'ятирічного сина і себе: «Життя немає смислу! Рано чи пізно комуністи нас розстріляють. Ми всі приречені. Я зроблю вибір за свою сім'ю!»" Подібні випадки справляли на американських та англійських солдатів, які допомагали чекістам відловлювати ДіПі, приголомшуюче враження.

Як виняток траплялися самогубства і серед опонентів ДіПі. Так, у $1947 \mathrm{p}$. підполковник Люкст, який очолював радянську репатріаційну місію у Регензбурзі, не зумів загітувати повернутися жодного ДіПі. У результаті отримав демісію та мав повернутися до СРСР. Розуміючи, що на нього чекає, вирішив вкоротити собі віку ${ }^{20}$.

Побутував ще один менш радикальний і дієвий спосіб уникнути репатріації: навмисне заподіювання собі каліцтва. У такому разі переміщені особи та біженці потрапляли до лікарні ${ }^{21}$ i на певний час ставали недосяжними для радянських репатріаційних комісій.

Інший вид політичного протесту, до якого вдавалися переміщені особи та біженці, становили втечі з ДіПі таборів до/під час прибуття радянських репатріаційних комісій. Біля таборових приміщень на високому стовпі знаходився гучномовець. За його допомогою таборяни дізнавалися важливу інформацію, зокрема і попередження про приїзд радянських репатріаційних комісій. Почувши сигнал, вони докладали зусиль поки не було запізно на певний час втекти з табору та перечекати в безпечному місці, приміром, у лісі ${ }^{22}$.

До слова, частина переміщених осіб і біженців вважала за краще жити індивідуально (знімати кімнату чи квартиру), а не в таборі. На їхню думку, живучи розпорошено вони були більш недосяжні чекістам, на відміну від організованої таборової громади. Інші ж навпаки надавали перевагу проживанню в таборі, оскільки сподівалися, що спільними зусиллями легше протистояти ворогам. Кожен мав свою стратегію виживання та боротьби.

Страх перед примусовою репатріацією до СРСР залишив глибокий слід у душах переміщених осіб і біженців з України. Навіть з відстані понад 70 років вони, пригадуючи

\footnotetext{
${ }^{18}$ «Наставникам, хранившим юность нашу...»: Педагогика и педагоги русского зарубежья: сб. ст. / сост. и вступ. ст. Л.С. Оболенской-Флам, О.П. Раевской-Хьюз. Москва: Дом русского зарубежья имени Александра Солженицына; Русский путь, 2017. С. 135.

${ }^{19}$ Воскобійник Г. Свобода і далі... С. 105.

${ }^{20}$ Регенсбург: статті - спогади - документи... С. 110.

${ }^{21}$ Клименко М. Из трех миров... С. 136.

${ }^{22}$ Особистий архів О.А. Подобєд. Анкета Л.О. (1933 р.н.). Арк. 9.
} 
свої найбільші страхи в епоху ДіПі, називали тільки загрозу примусової репатріації до $\mathrm{CPCP}^{23}$.

Значно складнішим завданням була втеча 3 радянських репатріаційних i фільтраційних таборів. Це вдавалося окремим сміливцям. у такий спосіб вони демонстрували свій протест проти повернення на «родіну». Приміром, у другій половині 1940-х рр. вдалося втекти 3 радянського фільтраційного табору, що розташовувався у невеличкому місті Жагань на кордоні Польщі 3 Німеччиною, трьом колишнім остарбайтерам, які в Україні працювали у Київському оркестрі. Спочатку музиканти добровільно погодилися на повернення додому. Однак через деякий час один з політруків фільтраційного табору проговорився: «Моліть Бога, щоб попасти на зруйнований Донбас, щоб на Колиму, або у Воркуту не попали» ${ }^{24}$. Вони втекли до американської окупаційної зони Німеччини.

Переміщені особи та біженці з України, які на момент капітуляції Німеччини опинилися у східній частині країни, контрольованій радянською владою, здійснювали спроби втеч на територію, яка знаходилася у сфері впливу альянтів. Приміром, скульптор Микола Мухін у 1945 р. під час спроби пробратися до Західної Німеччини був заарештований радянським військовим командуванням з метою репатріації до СРСР. Однак радянські керманичі вирішили не поспішати повертати М.Мухіна на рідну Донеччину та запропонували виконати групу скульптур для військових поховань радянських громадян у Німеччині.

Важко сказати, чому скульптора по завершенні роботи (середина 1945 р.) не репатріювали, можливо, вирішили поки що залишити в Німеччині 3 практичних міркувань. у 1947 р. Микола Мухін під псевдонімом Богдан Дунай разом 3 родиною зміг втекти до американської окупаційної зони Німеччини ${ }^{25}$, а згодом виїхав до США.

Оскільки репатріації до Радянського Союзу підлягали ті громадяни, які проживали на його території в кордонах, дійсних станом на 1 вересня 1939 р., то частина тих, хто не бажав повертатися (уродженці Наддніпрянщини або, як казали галичани, Великої України) змушена була подбати про внесення скорегованої інформації в анкети, таборові книжки, а також у документи, що посвідчували особу. Якщо у роки війни з метою уникнення сумної долі остарбайтерів «змінювали» рік народження, то в епоху ДіПі - місце народження, обираючи населений пункт, що знаходився на початок Другої світової війни на території Польщі; за потреби змінювали і прізвища.

Посвідки зі скорегованими даними можна було отримати в Українському Червоному Хресті $^{26}$, їх таємно виготовляли в ДіПі-таборах. Приміром, один з членів управи табору в Мангаймі організував групу «Statenloss» (укр. «Людина без громадянства»), яка виготовляла документи про те, що ДіПі до революції 1917 р. народилися в Польщі. Багато небайдужих допомагали чим могли: галичани та емігранти другої хвилі надавали для зразка оригінали своїх документів, художник Василь Кричевський-молодший надавав свої послуги як

\footnotetext{
${ }^{23}$ Особистий архів О.А. Подобєд. Анкета Валентина Забіяки (1933 р.н.). Арк. 3; Особистий архів 0.А. Подобєд. Анкета Олеся Ломацького (1932 р.н.). Арк. 7; Особистий архів О.А. Подобєд. Анкета Л.3.О. (1935 р.н.). Арк. 6; Особистий архів О.А. Подобєд. Анкета Л.О. (1933 р.н.). Арк. 9.

${ }^{24}$ Мірошник А. Музика і доля... С. 89.

${ }^{25}$ Яців Р. Зайцеве у променях світової слави. День. Київ. 2017. № 46-47. 17 березня. С. 18.

${ }^{26}$ Бо Ти любив, в душі беріг... С. 220, 222.
} 
каліграф і графік, його дружина Олена Кричевська виготовляла печатки з картоплі. За спогадами доньки митців - Катерини Кричевської-Росандіч, робота 3 продукування фальшивих документів тривала 24 години на добу. Родина Кричевських і собі виготовила документи, які засвідчували їхнє народження в Чехії ${ }^{27}$.

В Українському Червоному Хресті у Ганновері педагог Іван Юрченко, уродженець села Мельниківці Гайсинського повіту Подільської губернії отримав посвідку, в якій вказувалося місце народження Перемишль. Піаніст Анатолій Мірошник, прописуючись до польського ДіПі-табору, мешканці якого не хотіли репатріюватися до Польщі, записав в анкеті, а комендант - у таборовій книзі місце народження не Київ, а Кельце ${ }^{28}$.

Подекуди ДіПі змінювали прізвище. Передовсім це стосувалося «східняцьких» прізвищ, що закінчувалися на -енко. Приміром, диригент хору «Україна» Нестор й Анастасія Городовенки у Західній Німеччині перебували під прізвищем лохвицьких родичів Анастасії Нестеровських ${ }^{29}$. До таких маніпуляцій вдавалися й хористи «України», уродженці Наддніпрянщини. У свою чергу російський поет Микола Марченко, за власним висловом, обрав собі загадкове прізвище Моршен, за яким не можна було визначити національність і таким чином уникнути примусової репатріації ${ }^{30}$

Подібні маніпуляції були виправдані. Члени радянських репатріаційних комісій знали, до яких хитрощів зі зміною місця народження вдавалися українці. Тому викликали ДіПі зі «східняцькими» прізвищами на перевірку, навіть, якщо у документах зазначалося, що вони народилися на території Польщі. Під час співбесіди «поляки» мали продемонструвати володіння мовою, а також довести, що знають відповідні топоніми й ін. Оскільки не всі «східняки» могли успішно пройти таку перевірку, набуло поширення таке

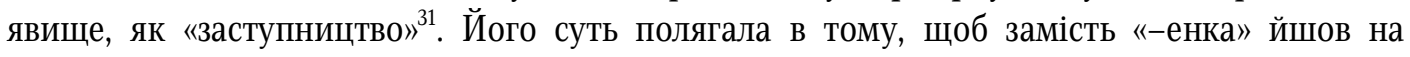
співбесіду галичанин. В іншому разі «поляк» попередньо шукав родину з Галичини і вивчав від них різні деталі про їхнє місто чи село ${ }^{32}$.

Героїня роману сучасної письменниці Марини Гримич «Клавка» Єлизавета Прохорова, яка була в складі радянської репатріаційної комісії, наголошувала, що ДіПі попри непевність свого становища, з гідністю трималися під час перевірок і співбесід: «Вони люто ненавидять усіх нас. I вони, повір мені, далеко не жалюгідні, як тут їх інколи описують. Повір мені, Нелько, це - сила. Вони по суті - хто? Біженці! Голодранці! Вони тікали під час війни в Німеччину з двома клунками і своїми ідеалістичними уявленнями про вільну Україну. А бачила б ти, як вони трималися на наших співбесідах: не менше, як лорди! І як вони вкладали в свою чемну мову все презирство до нас!»33.

Російська письменниця Олена Сабурова у своїй «ДіПілогічній абетці» 3 гумором описала типові відповіді ДіПі, які можна було почути під час подібних перевірок: «щМмммм» - зазвичай відповідає Діпі на питання комісії, хто він такий. «Я, власне кажучи, югослав, але

\footnotetext{
${ }^{27}$ Кричевська-Росандіч К. Мої спогади... С. 104.

${ }^{28}$ Мірошник А. Музика і доля. Київ: Музична Україна, 2008. С. 91.

${ }^{29}$ Шибанов Г. Нестор Городовенко. Київ: Видавництво імені Олени Теліги, 2001. С. 142.

${ }^{30}$ Агеносов В. Восставшие из небытия. Антология писателей Ди-Пи и второй эмиграции. Москва: АИРО-XXI; СПб.: Алетейя, 2014. С. 419.

${ }^{31}$ Бо Ти любив, в душі беріг... С. 222.

${ }_{32}$ Залеська Онишкевич Л. Бомби, границі і два праві черевички... С. 129.

${ }^{33}$ Гримич М. Клавка... С. 143-144.
} 
народився в Литві, проживав до 1938 року в Румунії, а за національністю та релігією штатенлос, польський підданий. 3 іноземних мов, крім російської, розумію українську» ${ }^{34}$.

Вносили рятівні корективи у документи не лише ДіПі з України, а й Росії. Піаніст Анатолій Мірошник згадував, що багато росіян з Росії, України та Білорусії видавали себе за українців, оскільки так було безпечніше ${ }^{35}$; частина записувалася як уродженці Литви чи Латвіï $^{36}$. Російський історик Олександр Фоменко описав, як родич італійського короля князь С. Романовський, герцог Лейхтенберзький - офіцер Російського імператорського флоту, ветеран Першої світової війни і білогвардієць видавав переміщеним особам і біженцям 3 Росії свою поруку в тому, що вони проживали до 1 вересня 1939 р. поза межами СРСР. Це у свою чергу дозволяло легалізуватися на території Італії й отримати візу, наприклад, до Франції (обидві країни не давали жодних зобов'язань в Ялті).

Переміщені особи та біженці з України не мали у своєму розпорядженні такі потужні пропагандистські засоби, як СРСР. Проте українська інтелігенція зуміла створити у Західній Німеччині низку газет і журналів («Визвольна політика», «Неділя», «Українська трибуна», «Українські вісті», «Час»), які взяли участь в інформаційній війні з Радянським Союзом. На їхніх шпальтах номер від номера публікувалися матеріали, в яких редактори та дописувачі декларували свій політичний протест проти примусової репатріації. Серед них - матеріали 3 історії українських національно-визвольних змагань першої чверті ХХ ст., статті про репресії в СРСР, про протиправну діяльність радянських репатріаційних комісій, а також фейлетони, в яких пояснювалися причини небажання повертатися на «родіну». У такий спосіб українці створювали свій інформаційний наратив, що мав протистояти радянському.

Попри всі зусилля редакторів газет, які видавалися в епоху ДіПі українською мовою, їхніми читачами були переважно переміщені особи та біженці з України. До слова, 3 великим інтересом їх читали радянські агенти та посадовці відповідних органів у СРСР ${ }^{38}$.

Однак 3 аргументами на користь неповернення до СРСР потрібно було ознайомлювати переважно англомовних посадових осіб і рядових виконавців наказів. Щоб голоси тисяч українців були почуті, потрібно було промовляти англійською. Незабаром такий текст з'явився, щоправда, спочатку українською мовою.

Наприкінці 1945 р. у кухні табору переміщених осіб у Гауштетені біля Аугсбурга Іван Багряний написав памфлет з промовистою назвою «Чому я не хочу вертатись до СССР?». Текст складається 3 передмови та 14 невеликих розділів. Ключем до розуміння основної ідейної спрямованості твору став епіграф. За епіграф автор взяв власні слова, які на сьогодні вже встигли стати крилатими: «Я вернуся до своєї Вітчизни 3 мільйонами своїх братів і сестер що перебувають тут, в Европі, і там, по сибірських концентратах, тоді, коли тоталітарна кривава більшовицька система буде знесена так як і гітлерівська. Коли НКВД піде вслід за Ґестапо, коли червоний російський фашизм щезне так, як щез фашизм німецький...» ${ }^{39}$.

\footnotetext{
${ }^{34}$ Агеносов В. Восставшие из небытия... С. 542.

${ }^{35}$ Мірошник А. Музика і доля... С. 89.

${ }^{36}$ Клименко М. Из трех миров... С. 138, 141.

${ }^{37}$ Рутченко-Рутыч Н.Н. Средь земных тревог... С. 6.

${ }^{38}$ ЦДАГО України. Ф. 1. Оп. 23. Спр. 5166. Арк. 100.

${ }^{39}$ Багряний I. Чому я не хочу вертатись до СССР? Винипег: Ukrainian national publishing company, 1946. С. 3.
} 
у брошурі публіцист аргументував небажання тисяч переміщених осіб і біженців 3 України повертатися до Радянського Союзу. Серед основних причин протидії репатріації на «родіну» Іван Багряний назвав репресії радянської влади проти українського народу, які проводилися протягом 1929-1939 рр. По-перше, знищення селянства в результаті спеціально організованого владою Голодомору 1932-1933 рр. в Україні, який забрав життя понад 5 млн. осіб. На думку І. Багряного, «знищення “куркуля, як класи” в дійсності було для нас знищенням України як нації, бо вона на 70\% селянська» ${ }^{40}$. По-друге, знищення «ворогів народу» - інтелігенції, з метою «позбавити український народ духовної верхівки, що змагалася до свободи й соціяльної справедливості» ${ }^{41}$. Публіцист апелював до історичної пам'яті європейців, до трагічних подій і новітніх тиранів, які лише нещодавно стали історією. Він наголосив, що українську інтелігенцію «вимордувано в такий спосіб, що й Гітлер міг би позаздрити й навчитись. Страхіття Дахав і Бухенвальду не перевищують страхіть безлічі енкавудистських катівень та концентраків» ${ }^{42}$. По-третє, знищення духовенства, антирелігійні кампанії.

Масові репресії, які проводилися в СРСР наприкінці 1920 - 1930-х рр. проти своїх же громадян мали на меті упокорити український народ, зламати його опір новій владі. Внутрішня політика була спрямована на денаціоналізацію українців, їхнє духовне та національне знищення 3 метою перетворення їх на «радянських людей», а «многонаціонального СССР» на «єдину червону імперію» ${ }^{43}$. Певною мірою мета була досягнута. Частина ДіПі, лише перебуваючи у повоєнні роки в Західній Німеччині, змогла познайомитися 3 автентичною українською культурою, традиціями та звичаями українського народу, відвідати Службу Божу та долучитися до відзначання релігійних свят. Приміром, родина етнолога Олекси Воропая уперше святила паски в українській церкві саме на німецькій землі ${ }^{44}$. І це був непоодинокий випадок.

Окремо публіцист пояснив, чому керівництво СРСР попри спротив ДіПі докладало титанічних зусиль для репатріації усіх своїх громадян і дезінформувало світову громадськість, стверджуючи, що ті, хто не хоче повертатися, нібито, є воєнними злочинцями. За Багряним, усі ДіПі становлять небезпеку для керівництва Радянського Союзу, оскільки є носіями інформації про справжню суть радянської влади ${ }^{45}$. Очільник наддержави боявся, щоб не відбувся витік інформації.

Брошура «Чому я не хочу вертатись до СССР?» була надрукована у 1946 р. в Канаді за спонсорської підтримки Комітету українців Канади. Незабаром після виходу вона стала бестселером у Західній Німеччині. Протягом 1946-1947 рр. памфлет можна було придбати у будь-якому таборовому кіоску. ДіПі купували для себе та на подарунок, у тому числі й для членів окупаційних адміністрацій. У 1947 р. один ДіПі, пояснюючи ЮНРРА причини, через які не бажає повертатися до СРСР, лише надіслав брошуру І. Багряного, підкресливши олівцем ключові аргументи ${ }^{46}$.

\footnotetext{
${ }^{40}$ Ibid. C. 12 .

${ }^{41}$ Ibid. C. 17.

${ }^{42}$ Ibid.C. 20-22.

${ }^{43}$ Ibid. C. 11.

${ }^{44}$ Bоропай О. В дорозі на Захід... С. 193.

${ }^{45}$ Багряний I. Чому я не хочу... С. 27.

${ }^{46}$ Регенсбург: статті - спогади - документи... С. 100.
} 
Із метою донесення змісту памфлету до широких кіл світової громадськості він одразу ж був перекладений професором Романом Смаль-Стоцьким англійською мовою ${ }^{47}$, а згодом побачив світ німецькою, іспанською й італійською мовами. Памфлет здобув великий резонанс у світі. Зміст праці Багряного наблизив західних політиків до розуміння справжніх причин небажання повертатися «на родіну»

Переміщені особи та біженці з України в усній і письмовій формі повідомляли членам радянських репатріаційних комісій, окупаційних адміністрацій, ЮНРРА чи IPО своє небажання повертатися до СРСР й пояснювали причини такого рішення. За допомогою окупаційних адміністрацій члени радянських репатріаційних комісій влаштовували зустрічі з переміщеними особами та біженцями з різних країн (України, Росії, Литви, Латвії, Естонії, Полыщі та ін.), на яких інформували про способи повернення до СРСР. Такі зустрічі проводили 1-2 представники радянської репатріаційної комісії, а також могли бути присутні представник окупаційної адміністрації та перекладач. До слова, останній нерідко навмисне здійснював некоректний переклад, що спонукало ДіПі самостійно перекладати американським чи англійським посадовцям.

Представники радянських репатріаційних комісій наголошували, що репатріація $€$ добровільною. Разом 3 тим зазначали, що всі радянські громадяни будуть змушені повернутися на батьківщину. Окрім цієї дезінформації, вони також поширювали й іншу на виїзд за океан ДіПі повинні отримати дозвіл від радянської влади. Посадовці намагалися спростувати інформацію, яку в Західній Німеччині поширювали «вороги народу», про репресії, які організувало сталінське керівництво в 1930-х рр., а також про те, що ті, хто повернувся до СРСР підлягали судам і засланням. Натомість наголошували, що ця категорія населення користується такими ж правами і свободами, як і інші громадяни СРСР.

Під час таких зустрічей відводився час на запитання і відповіді. Сучасник подій Іван Максимчук у праці «Совітський п’ястук над українською оселею Ганггоферзідлюнг в Реґенсбурзі» описав одну з зустрічей, що відбулася у другій половині серпня 1945 р. в австрійському місті Брук. Один з українщів, щоб пояснити, чому він не хоче повертатися до СРСР (передусім це адресувалося представнику американської окупаційної адміністрації, який був присутній на заході), поставив радянському посадовцю кілька питань. Зокрема, «Чи вам, пане лейтенант, відомо, що у 1921/22 і 1932/33 був на Україні такий великий голод, що жертвою його стало кілька мільйонів українського населення, у той час, коли українською пшеницею заграниця годувала свої безроги? Що ви на це скажете і яка причина цього штучно викликаного голоду?» ${ }^{48}$. Лейтенант відповів, що в ті роки він сам жив в Україні і йому нічого не відомо про голод, а потім попросив, щоб ДіПіст назвав своє ім'я та прізвище, місце народження і проживання в Україні. У підсумку кожен залишився при своєму: ДіПі не виявили добровільного бажання повертатися до СРСР.

Наведений сценарій зустрічей переміщених осіб і біженців 3 України та представників радянської репатріаційної комісії був типовий. Представники української громади певного табору, делеговані на зустрічі з членами радянських репатріаційних комісій, чи таборяни, індивідуально декларували своє небажання повертатися на «родіну» через репресії. У свою чергу латвійці, литовці й естонці на повний голос заявляли, що вони

\footnotetext{
${ }^{47}$ Костюк Г. Зустрічі і прощання... С. 182.

${ }^{48}$ Регенсбург: статті - спогади - документи... С. 89.
} 
ніколи не були і не хочуть бути радянськими громадянами, наголошуючи, що СРСР окупував їхні країни ${ }^{49}$. Важливо, що на цих зустрічах були присутні представники окупаційної адміністрації, які могли скласти своє уявлення про причини небажання ДіПі повертатися додому.

Наприкінці 1946 р., коли добігала кінця каденція ЮНРРА, міжнародна допомогова організація поширила серед таборян Західної Німеччини летючку за підписом репатріаційного референта ЮНРРА Оле Нілсона. Вона була надрукована українською, російською, білоруською, латиською та литовською мовами. Мета документу - спонукати переміщених осіб і біженців до репатріації («Вигляди на емігрування звідси дуже малі. Тяжко буде працювати під зверхністю німців. Може все таки, можливо поїхати до дому? УНРРА просить Вас розважити на це, чи не поїхати б Вам додому») та з'ясувати причини небажання повертатися до СРСР («УННРА знає, що у Вас є немало проблєм до розвязання у звязку з репатріацією. Є багато невияснених, невирішених питань. Щоб ми Вам допомогли, ми мусимо знати що Вас утримує від повороту» ${ }^{50}$ ). Свої міркування щодо останнього слід було писати на звороті летючки та подавати до ЮНРРА, а відповіді на них мали публікуватися у таборових бюлетенях.

у таборі в Регенсбурзі більшість ДіПі проігнорувала звернення у летючці, відповіді дали менше 10 осіб - 5 українців, 2 росіянина і латиш. Усі дописувачі вирішили залишитися анонімними, окрім двох росіян, які підписали спільну відозву. Свої причини небажання повертатися додому українці аргументували репресіями, що мали місце в СРСР. На думку респондентів, вони проводилися за соціальною (заможні селяни, так звані «куркулі»), національною, релігійною ознаками. Один з них наголосив, що ДіПі потребують допомоги «щодо переселення, виїзду будь куди, де б можна було вільно жити та працювати», а інший не виключив можливості повернення додому за умови припинення «непотрібного переслідування людини» ${ }^{51}$. У свою чергу росіяни пропонували провести два експерименти і дали свої прогнози щодо їхніх результатів: дозволити усім радянським громадянам вільний виїзд з СРСР - жодного некомуніста в країні не залишиться; запропонувати прихильникам комунізму на Заході кілька років пожити у Радянському Союзі - вони назавжди вилікуються від комунізму.

Пасивні поведінкові практики, які відображали невдоволення ДіПі примусовою репатріацією до СРСР, становили незначний відсоток серед інших видів політичного протесту. До них можна віднести ігнорування переміщеними особами та біженцями заходів, які проводили члени радянських репатріаційних комісій. Серед них - проведення зустрічей 3 представниками радянських репатріаційних комісій, які роз'яснювали обставини повернення до СРСР, відповідали на запитання ДіПі; роздавання по ДіПітаборам радянської преси.

Висновки. Протест переміщених осіб і біженців проти примусової репатріації став соціально-політичним феноменом епохи ДіПі. До активних протестних дій ДіПі належали боротьба із застосуванням фізичної сили 3 членами репатріаційних комісій та американськими й англійськими солдатами, які намагалися насильно схопити ДіПі для

\footnotetext{
${ }^{49}$ Регенсбург: статті - спогади - документи... С. 89-90.

${ }^{50}$ Ibid. C. 99.

${ }^{51}$ Ibid. C. 100-101.
} 
відправки на «родіну»; самогубства; навмисне завдання собі каліцтва; втечі з ДіПітаборів/радянських репатріаційних таборів; втечі зі Східної Німеччини до Західної Німеччини; тимчасове переховування поза ДіПі-таборами; підробка документів; друк статей, окремих публіцистичних праць, художніх творів; індивідуальне повідомлення членам радянських репатріаційних комісій/представникам окупаційних адміністрацій, ЮНРРА чи IPО своєї незгоди до репатріації; повідомлення уповноваженим українською громадою певного табору (або частини табору) членам радянських репатріаційних комісій / окупаційних адміністрацій, ЮНРРА чи IPО незгоди до репатріації й ін.

Низка протестних акцій, до яких змушені були вдатися ДіПі, спонукав на початку червня 1945 р. папу римського Пія ХІІ висловитися проти насильницької репатріації українців. Незабаром уряди США та Великої Британії переглянули своє ставлення до репатріації до СРСР, припинили безумовне сприяння діяльності радянських репатріаційних комісій у Західній Німеччині, а восени 1945 р. припинили примусову репатріацію. Щоправда, на той час уже білышість українців (понад 2 млн.) опинилася на території СРСР.

У травні 1946 р. відбувся перегляд Ялтинських домовленостей. Як наслідок рекомендовано, що «слід застосовувати принцип примусової репатріації тільки до тих громадян Радянського Союзу, які були захоплені в німецьких мундирах, або які були учасниками збройних сил СРСР станом на чи після 22 червня 1941 р. і яких згодом не було звільнено від служби, або за наявності доказів, що вони надавали допомогу та підтримку ворогові ${ }^{52}$.

Політичний протест ДіПі певною мірою вплинув на еволюцію тактики СРСР i характер поведінки членів радянських репатріаційних комісій протягом другої половини 1940-х рр. Якщо у 1945 р. вони діяли зухвало і нахабно, силоміць ловили переміщених осіб і біженців й відправляли на «родіну», то згодом почали проводити зустрічі з тими, хто не хотів повертатися та переконували змінити своє рішення. Протягом 1946-1948 рр. наполегливішою стала пропаганда за допомогою 3МI та агітбригад громадсько-політичних діячів з України, Білорусії, Естонії, Литви та Латвії. На проведення пропагандистських заходів не шкодували коштів. Приміром, Міністерство фінансів УРСР у третьому кварталі 1948 р. виділило для проведення відповідної масово-політичної роботи 250 тис. крб. ${ }^{53}$

IPO, що заступила у 1947 р. ЮНРРА, подала перелік умотивованих причин, з яких ДіПі можуть опиратися репатріації на батьківщину. Серед них - переслідування або страх перед переслідуванням з расових, релігійних, національних причин або з політичних переконань; панування в країні тоталітарного антидемократичного чи терористичного режиму ${ }^{54}$.

Дружина 34-го президента США Елеонора Рузвельт виступала на захист тих переміщених осіб і біженців, яких намагалися примусово повернути до СРСР. Протягом 1945-1951 pр. вона очолювала Комісію ООН з прав людини. За її активної участі наприкінці 1948 р. Генеральна Асамблея ООН прийняла Загальну декларацію прав людини. 13-та стаття документу гарантує вільне пересування і обрання місця проживання, а 14-а - право шукати притулку від переслідувань в інших країнах і користуватися цим притулком ${ }^{55}$.

\footnotetext{
${ }^{52}$ Хромейчук 0. Радянська репатріаційна місія та британська комісія 3 перевірки біженців. URL: http://uamoderna.com/md/khromeychuk-repatriation

${ }^{53}$ ЦДАГО України. Ф. 1. Оп. 23. Спр. 5166. Арк. 4-24, 41-42.

${ }^{54}$ Час. Нюрнберг. 1947. 31 серпня. Ч. 35.

${ }_{55}^{5}$ Загальна декларація прав людини. Прийнята і проголошена резолюцією 217A (III) Генеральної Асамблеї ООН від 10 грудня 1948 p. URL: https://zakon.rada.gov.ua/laws/show/995_015\#Text
} 
Як наслідок тисячі ДіПі з України й інших країн отримали шанс на життя, на життя у демократичних країнах, в яких принцип верховенства права діє не лише на папері, а й у житті. Прибувши до США, Канади, Австралії й інших країн, колишні переміщені особи та біженці з України, маючи за плечима досвід політичної боротьби проти свавілля радянських керманичів в Україні та Західній Німеччині, продовжували боротися за право жити у вільній Україні.

Домовленості трьох лідерів держав у Ялті 1945 р. створили небачений доти прецедент примусової репатріації. Репатріація переміщених осіб і біженців до СРСР у другій половині 1940-х рр. застосовувалася вперше у світовій практиці. Не бажаючи повертатися до сталінського СРСР, беззахисні переміщені особи та біженці з України, які один на один опинилися з радянськими репатріаційними комісіями та англійськими й американськими військовими, у різний спосіб висловлювали свій політичний протест. Врешті їхні голоси було почуто, й США та Велика Британія припинили примусову репатріацію. Вирішити проблему «неповерненців» можна було лише в один спосіб організовано розселити іхх в інші країни, що протягом другої половини 1940 - початку 1950-х рр. і було зроблено.

\section{Olena Podobied}

\section{Repatriation - no!}

\section{The political protest of the West German DP in the second half of the 1940s}

Abstract: Purpose. Based on a broad source base, we aim to identify and analyze the forms and effectiveness of the political protest of displaced persons and refugees from Ukraine in West Germany in the second half of the 1940s in response to forced repatriation to the USSR. Methodology. General scientific methods such as analysis and synthesis, induction and deduction were used during the research. Among the special-historical methods are the methods of bibliographic and archival heuristics, comparative-historical, problemchronological and biographical. In this study, we use the term «political protest», which is understood as follows: political protest - individual or group action of displaced persons and refugees from Ukraine, which consisted of disagreement with the forced repatriation campaign to the USSR, which unfolded in the second half of the 1940s in West Germany. Scientific novelty. The forms and consequences of the political protest of displaced persons and refugees from Ukraine in West Germany in the second half of the 1940s were first identified and analyzed. Main results. The protest of displaced persons and refugees against forced repatriation became a socio-political phenomenon of the DP era. Protest actions taken by the DP forced the governments of the United States and Great Britain to reconsider their attitude to repatriation to the USSR, they stopped promoting Soviet repatriation commissions in West Germany, and in the fall of 1945 they stopped forced repatriation.

Keywords: repatriation, displaced persons and refugees from Ukraine, political protest, West Germany, USSR 